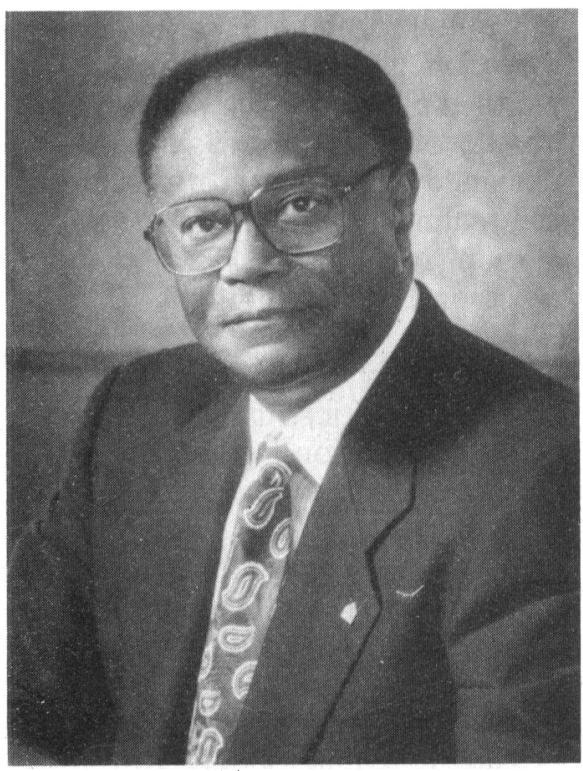

Eddie N. Williams

gave Williams its "National Builder Award" for his outstanding contributions to the nation. In 1991, Washingtonian magazine named Williams one of 16 "Washingtonians of the Year."

Between 1968 and 1972, Williams was vice president for public affairs and director of the Center for Policy Study at the University of Chicago. In the $1960 \mathrm{~s}$, he held several positions in the U.S. Department of State and on the U.S. Senate Committee on Foreign Relations.

For his leadership and exemplary service, Mr. Williams has received numerous honors and awards. In 1988, he received the prestigious MacArthur Foundation "genius award" for his work "in enabling black leaders, politicians and others to highlight the needs of the nation's poor and disenfranchised." In addition to honorary degrees from Bowie State University in Maryland and the University of the District of Columbia, Mr. Williams has been honored by numerous institutions, including the Congressional Black Caucus, the Southern Christian Leadership Conference, and the University of Illinois, his alma mater. In 1986, the National Joumal named him as one of the 150 people in the United States, outside the government, who have had the greatest impact on what the federal government does.

Williams also is active in a num- ber of influential associations. Together with the heads of the $\mathrm{Na}$ tional Urban League and the NAACP, he is one of the founding members of the Black Leadership Forum, a coalition of the most influential national black public service organizations in the U.S., and he currently serves as its secretarytreasurer.

$\mathrm{He}$ is on the boards of Independent Sector, National Opinion Research Center, National Endowment for Democracy, Riggs National Bank of Washington, Japan-America Society of Washington, Public/Private Ventures, The Promus Companies, Inc. and Grumman Corporation.

He serves as chairman of the Board of Directors of the National Coalition on Black Voter Participation and of the PEW Partnership for Civic Change.

\section{APSA Council Confirms 1996 Annual Meeting Program Committee}

At its April 8 meeting, the APSA Council unanimously accepted the proposed 1996 Program Committee submitted by president-elect Arend Lijphart, University of California, San Diego, and the 1996 program co-chairs, Ronald Rogowski, University of California, Los Angeles,

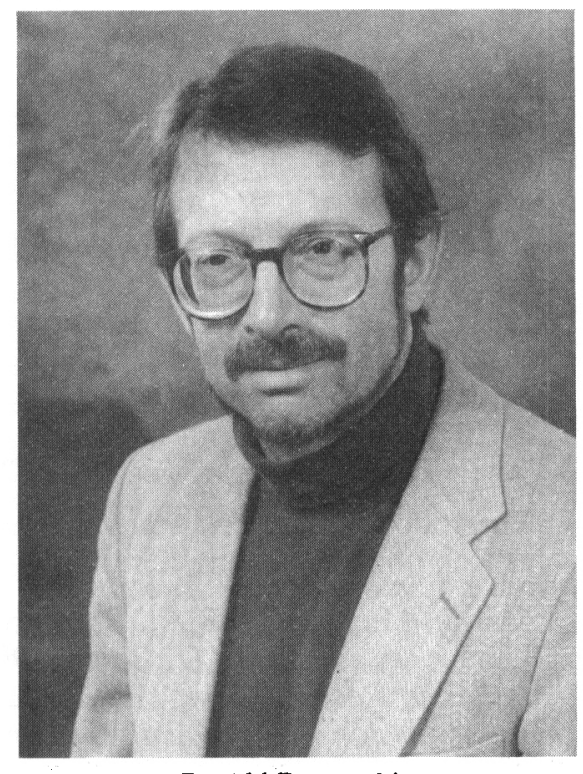

Ronald Rogowski

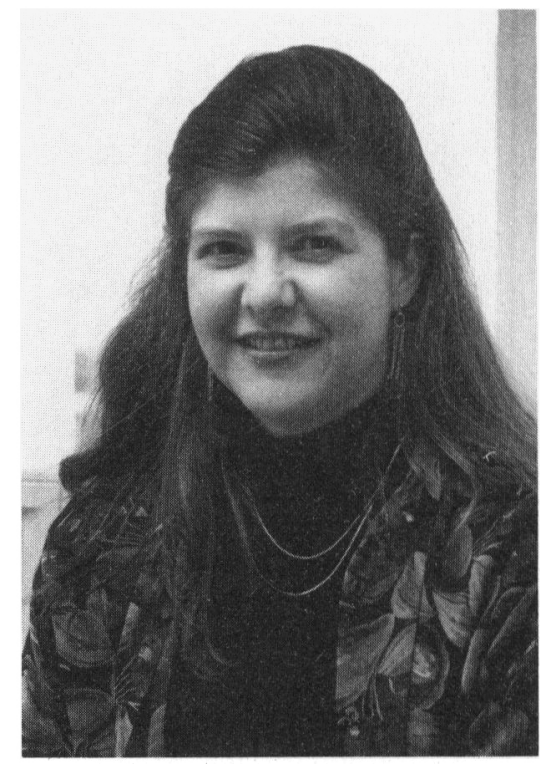

Jennifer Hochschild

and Jennifer Hochschild, Princeton University.

The 1996 Program Committee consists of 46 divisions representing the diverse fields of interest within the discipline. The call for papers for the 1996 program will appear in the September issue of $P S$. The 92nd Annual Meeting will return to the San Francisco Hilton Hotel and Towers from August 29 through September 1, 1996. The annual meeting was last held in San Francisco in 1990. The 1990 meeting went on to set the standard for meeting size and complexity for the first half of the 1990s.

\section{Putnam Named First Ithiel de Sola Pool Lecturer}

Robert D. Putnam of Harvard University has been selected as the recipient of the APSA's first triennial Ithiel de Sola Pool Award and Lectureship. The award is given to a scholar selected to explore the implications of research on issues of politics evoking the broad range of scholarship by Ithiel de Sola Pool. The presentation may draw from many fields, including: political communications, political theory, political behavior, science and technology policy, and international affairs.

Ithiel Pool received a $\mathrm{Ph} . \mathrm{D}$. from 